\title{
EFFICIENT REMITTANCE SERVICES FOR DEVELOPMENT IN THE PACIFIC
}

John Gibson, Geua Boe-Gibson, Halahingano Rohorua and David McKenzie*

Capital inflows to the Pacific islands from aid, foreign investment and remittances are an important source of development finance. Remittances are the fastest growing; they now total US\$ 400 million per year and can be expected to grow even further as labour mobility is used to deal with seasonal labour shortages in Australia and New Zealand and limited job opportunities in the Pacific. The transaction costs of sending remittances to the Pacific islands are very high for the most widely used methods. This paper examines the New ZealandTonga remittance corridor, where typical transactions involve costs in the order of 15 to 20 per cent for bank drafts and transfers through money transfer companies such as Western Union. Cheaper transfer methods using automated teller machines (ATMs) are feasible and have transaction costs of less than 5 per cent but are not widely used. This spread of 10 percentage points between the most popular and the cheapest remittance methods means a potential loss for Tonga of the equivalent of 4 per cent of GDP. Extrapolating from this remittance corridor to the rest of the Pacific, avoidable transaction costs may total US\$ 40 million per year. Hypotheses about the continued reliance on high transaction cost methods are examined and implications for development policy are discussed.

John Gibson, Geua Boe-Gibson and Halahingano Rohorua are, respectively, a professor, a research officer and a post-doctoral fellow at the Department of Economics, University of Waikato, New Zealand. David McKenzie is at the Finance and Private Sector Development Unit, Development Research Group, World Bank.

The survey data used here were originally funded by the World Bank, the Waikato Management School and a Marsden Fund grant. This funding is gratefully acknowledged, as are the assistance with data provided by the Ministry of Lands, Surveys and Natural Resources; the Statistics Office of Tonga; and survey respondents, helpful comments contributed by Alastair Bisley, Karen Nero and an anonymous reviewer and the hospitality extended during the drafting of this article by the Macmillan Brown Centre for Pacific Studies at the University of Canterbury. 


\section{INTRODUCTION}

Most poor people around the world lack access to competitive and efficient financial services. Very few benefit from a savings account, insurance, loans or a convenient and cheap way to transfer money. As Helms $(2006,1)$ notes:

"Financial services for the poor, often referred to as microfinance, cannot solve all the problems caused by poverty. But they can help put resources and power into the hands of poor and low-income people themselves, letting them make those everyday decisions and chart their own paths out of poverty."

While finance for economic development was traditionally viewed in a more aggregate sense, with large aid-financed transfers to State-run development banks, in recent years an emphasis has been placed on financial flows at the household and individual levels. This reflects the fact that market failures, in the form of imperfect and unequally distributed information (e.g. borrowers typically know more than lenders do about the risks of the project for which they are seeking financing), and high transaction and contract enforcement costs particularly affect poor or small entrepreneurs who lack collateral, credit histories, and connections (Beck, Demurgic-Kunt and Peria, 2007).

Migrants are one of the main sources of these microlevel financial flows; worldwide, they remit billions of dollars to their points of origin. These remittances have risen rapidly and now exceed the amount of money that developing countries receive as foreign aid (Ratha, 2003). They are especially important for small island developing countries, which have an average of 17 per cent of their population working overseas (Mckenzie, 2007). ${ }^{1}$ In Polynesian countries, such as Tonga and Samoa, emigration is even higher, with typically over one quarter of the population overseas (similar to the Caribbean). Consequently, remittances are very important in Polynesian countries, comprising 39 per cent of gross domestic product (GDP) for Tonga, 36 per cent for Tuvalu and 14 per cent for Samoa (World Bank, 2006).

While aid is still more important overall in the Pacific islands (see section II), remittances are growing faster than either aid or foreign direct investment and now total US\$ 400 million per year. Remittances can be expected to grow even further as short-term labour mobility is used as a mechanism to deal with seasonal labour shortages in Australia and New Zealand and limited job opportunities in the Pacific (Benson-Pope and Cunliffe, 2006; Maclellan and Mares, 2006; World Bank, 2006a).

1 This average is for island countries with populations below 1.5 million. 
Remittances provide a major source of investment, especially for human capital formation and microenterprises. For example, in the data from the authors' Pacific Island-New Zealand Migration Survey discussed below, almost one quarter of cash remittances reported by the sampled households in Tonga are earmarked for paying school fees. ${ }^{2}$ Brown (1994) and Brown and Connell (1993) also find that many remittances of both money and goods to Tonga and Samoa are used for investment, especially to set up microenterprises such as petty trading, and that, overall, remittances make a significant contribution to savings and investment.

However the transaction costs for the most widely used methods of sending remittances to the Pacific islands are very high. These high costs are unlikely to reflect the small size of the remittance market in the Pacific islands since the country we focus on, Tonga, receives approximately the same level of total remittances as much larger countries. For example, Ghana and Tonga both received approximately US\$ 65 million in remittances in 2003 (World Bank, 2006), but transaction costs to Ghana are only one third of those to Tonga. Since transaction costs are presumed to be higher the smaller the volume of remittance inflows, it seems likely that remittance services are even less efficient and the transaction costs even higher in other Pacific island countries where remittances are less common than in Tonga. These high transaction costs are linked to the remittance destination country rather than the country of origin; for example, the effective exchange rate commission when using Western Union to send 200 New Zealand dollars (NZ\$) from New Zealand is 10 per cent when the destination is Tonga versus only 3 per cent when the destination is the United States and 4 per cent when the destination is Australia.

The issue of transaction costs also matters because they vary widely. If all feasible methods of remitting to the Pacific were equally costly, there would be little room for public policy to reduce costs. However, according to estimates by Gibson, McKenzie and Rohorua (2006), the transaction costs on money transfers from New Zealand to Tonga range from 15 to 20 per cent when sending bank drafts or using money transfer companies like Western Union but are only 4 per cent when the recipient uses an automatic teller machine (ATM) to withdraw funds from an account set up by the remitter.

Similar patterns of remittance use are reported in other parts of the world. For example, Adams (2006) finds that in Guatemala, households receiving international remittances spend 58 per cent more on education than do households which receive no remittances. Households receiving remittances also spend a smaller portion of extra income on consumption and more on investment than those that do not receive remittances (Mckenzie, 2007). 
This spread of at least 10 percentage points between the most popular and the cheapest remittance methods could lead to a potential loss for Tonga of up to 4 per cent of GDP (given that remittances are 39 per cent of GDP) if remittances are sent through costly rather than cheap channels. In fact, the loss may be even greater since higher transaction costs may reduce the gross amount that remitters send if there is a negative cost elasticity of remittances. Thus, the net remittance received is lower both because the transaction costs take a larger share of the amount sent and because the transactions costs act like a tax and induce remitters to send less. According to calculations reported by Gibson, McKenzie and Rohorua (2006), the negative cost elasticity in the New Zealand to Tonga remittance channel means that Tonga might gain up to 28 per cent more in net remittance receipts if transaction costs could be lowered to the level prevailing in other regions.

The next section of this paper provides evidence of the growing importance of remittances in the Pacific. The data used to measure transaction costs and to examine hypotheses about the continued reliance on high-cost methods for the New Zealand-Tonga remittance corridor are discussed in section III. The transaction costs of remittances from New Zealand to Tonga are then described in section IV. Several hypotheses about the continued reliance on high transaction cost methods are examined in section $\mathrm{V}$ and the implications for development policy are discussed in section $\mathrm{Vl}$.

\section{FINANCIAL FLOWS IN THE PACIFIC}

Figure 1 presents evidence on the importance of aid, foreign direct investment and remittances in the most recent year available for each of the Melanesian and Polynesian countries and for Kiribati. Data on remittances to the other Micronesian countries are less readily available from international sources. Even for the countries with reported data, it is likely that remittances are understated, as some transfers probably occur through informal means such as travellers carrying cash back with them. Moreover, the data in figure 1 only relate to monetary remittances rather than the provision of goods in kind, for which there are no comparable cross-country data. ${ }^{3}$

3 McKenzie (2006) reports survey evidence that cash remittances from New Zealand to Tonga constituted only 63 per cent of the value of total gross remittances, with the remaining 37 per cent taking the form of goods. There are also substantial reverse flows, mainly of goods, particularly in the form of items that have cultural or symbolic value. The issue of non-cash remittances and their impact on the difference between the values of gross and net receipts requires more detailed research. 


\section{Figure 1. Financial flows in the Pacific}

(Percentage of GDP)

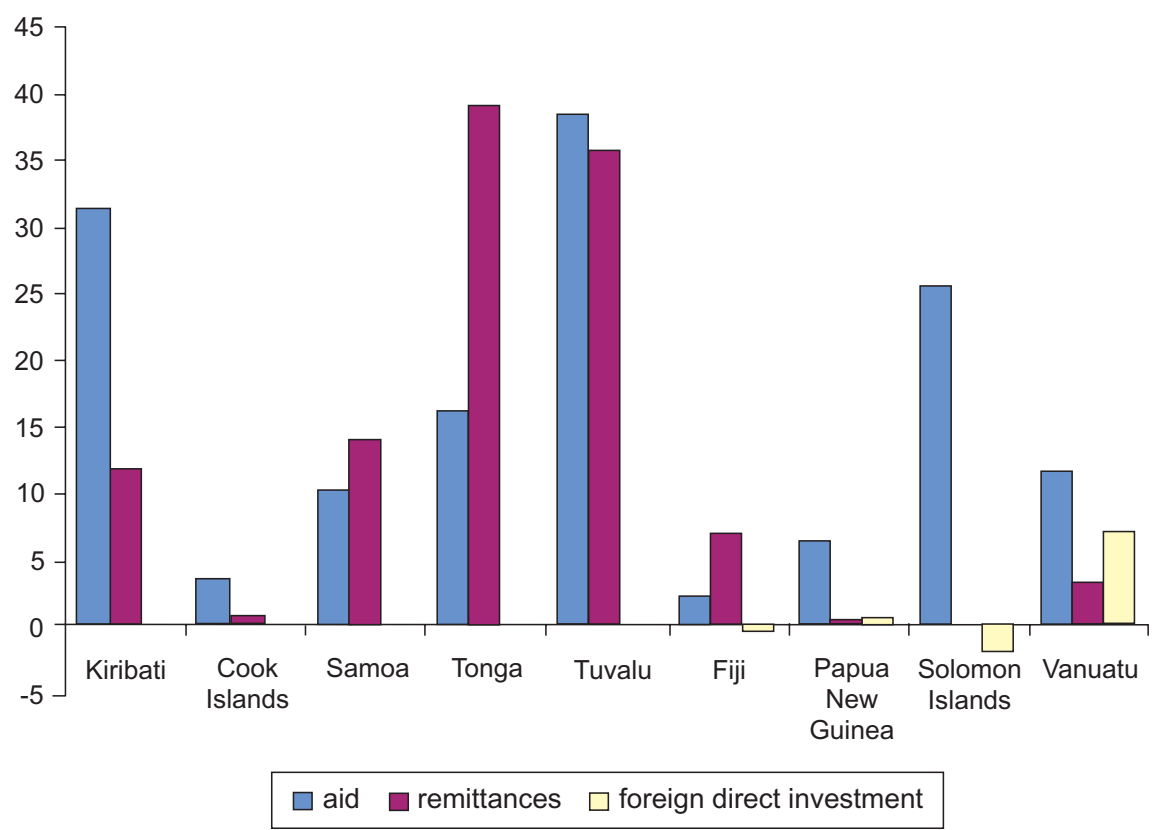

Sources: AusAID (2006), Asian Development Bank (2006).

For the countries in figure 1, aid is equivalent to 16.3 per cent of GDP, on average. This is somewhat higher than remittances, which amount to 12.5 per cent of GDP, far exceeding foreign direct investment, which represents only 0.6 per cent of GDP. Total remittances to the nine countries in figure 1 equal about US\$ 350 million per year. Thus, across all Pacific island economies (including those not in figure 1), it is likely that total remittances are now in the order of US\$ 400 million per year.

There is considerable regional variation in the relative importance of aid and remittances, reflecting the much more limited options for labour mobility in Melanesia compared with those in Polynesia. Outside of Fiji, where remittances have grown rapidly due, in part, to the participation of Fijian soldiers in overseas military and peacekeeping operations, remittances in Melanesia average only 1.2 per cent of GDP versus 14.6 per cent for aid. However, across the Polynesian countries, remittances average 22.5 per cent of GDP versus 17.2 per cent of GDP for aid receipts. Remittances are most important in Tonga, at 39 per cent of GDP, 
and for that reason the rest of the discussion and analysis in this paper is based on the Tongan experience.

The trend for remittances to increase much faster than aid receipts is illustrated in figure 2 for the case of Tonga. While aid receipts declined from US\$ 32 million in 1996 to less than US\$ 20 million in 2004, remittances grew substantially from US\$ 47 million to US\$ 90 million over the same time period. In terms of growth rates, remittances are increasing at almost 10 per cent per year versus a 3.8 per cent per year decline in aid receipts.

Figure 2. Financial flows to Tonga, 1996-2005

(Millions of United States dollars)

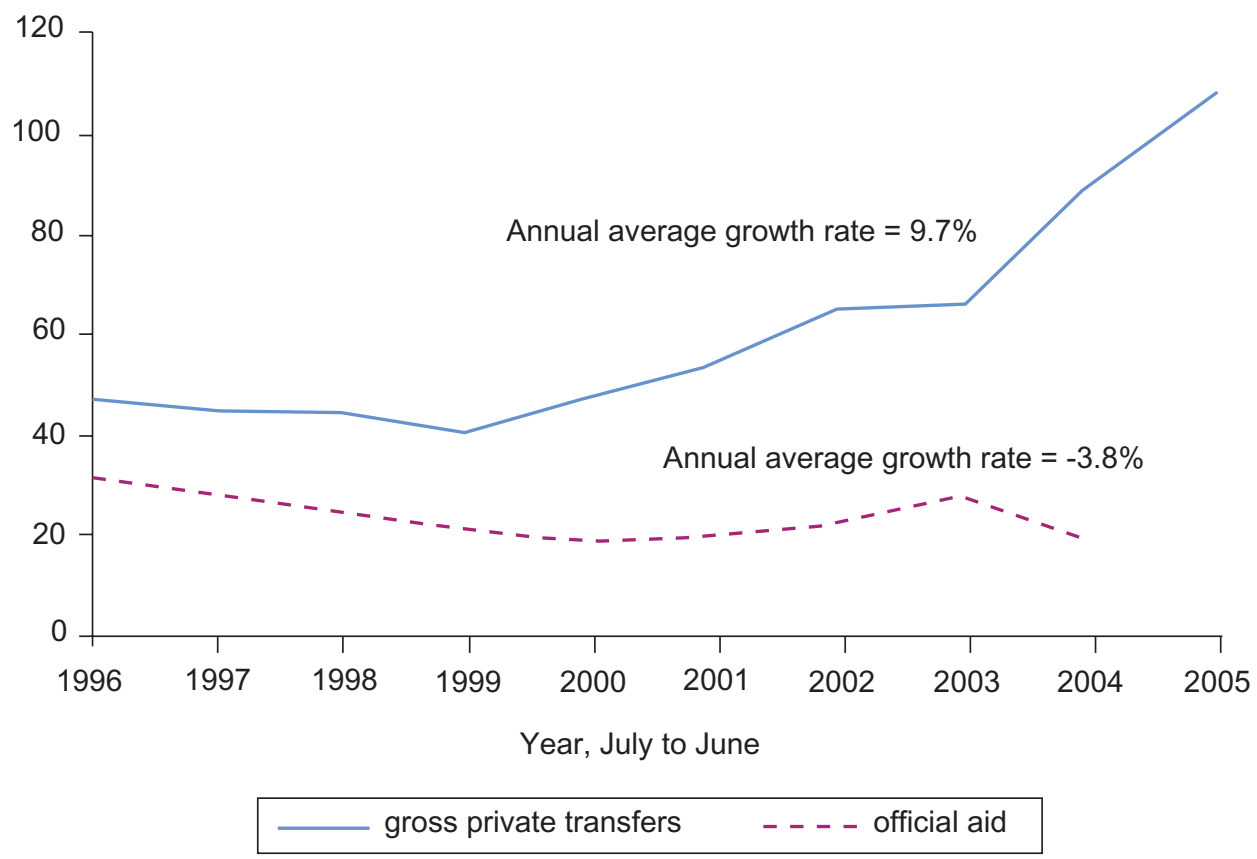

Sources: Remittance data from Connell and Brown (2005); National Reserve Bank of Tonga (various issues); aid data from World Bank (2007).

The trend in figure 2 emphasizes the importance of reducing the transaction costs of remittances for countries like Tonga. While aid efficiency is undoubtedly important, it relates to a declining source of external finance for some of the Pacific island countries, whereas the much less studied issue of remittance transaction costs relates to a rapidly increasing source of external finance for development in Tonga, and more broadly in the Pacific. 


\section{DATA}

Three types of data are used to measure transaction costs in the New Zealand-Tonga remittance corridor and to examine hypotheses about why high-cost methods continue to be chosen. The first consists of information gathered from banks and money transfer operators to measure both the fixed charges they impose on senders and recipients and the effective exchange rate commissions implied by the rate of exchange they offer. Detailed notes on these data are reported in Gibson, McKenzie and Rohorua (2006).

The second type of data comes from a sample of 101 recent Tongan immigrants to New Zealand who were surveyed as part of the Pacific Island-New Zealand Migration Survey (PINZMS), a comprehensive survey designed by the authors to measure multiple aspects of the migration process. A detailed description of the PINZMS sample and methods and various descriptive statistics on the data are reported by McKenzie, Gibson and Stillman (2007). The relevant aspect for the current study is that this survey has a detailed module on remittances, recording remittances sent and received in the form of money and goods and the channels used to send remittances. In addition to questions about knowledge and use of various methods of sending money back to Tonga, those interviewed after February 2006 (the last third of the sample, $n=36$ ) were also asked questions about factors such as accessibility and security that affected their choice of remittance method.

The third type of data is geographic data on population distribution, the road network and the location of all ATMs and Western Union outlets on the main island of Tonga, Tongatapu. This island contains two thirds of the Tongan population and most of its financial infrastructure, so it is a good location for considering the role that service accessibility for remittance recipients plays in determining the choice of remittance method. Specifically, the eight ATMs and five Western Union outlets on Tongatapu were geocoded and placed onto a digitized version of the road network to simulate the travel distance that the population would have to cover to reach the nearest ATM or Western Union outlet.

\section{THE TRANSACTION COSTS OF REMITTANCES}

There are two types of transaction costs associated with remittances. The first consists of fixed charges, such as the NZ\$25 that banks charge senders of a telegraphic (wire) transfer, the NZ\$ 5 to NZ\$ 8 that they charge for ATM withdrawals in another country (using a card linked to the remitter's account in New Zealand) or 
the NZ\$20 that Western Union charges for a money transfer. ${ }^{4}$ There may also be fees imposed on the recipient for receiving wire transfers or depositing bank drafts, in addition to costs for the remitter and the recipient to communicate with each other (e.g. mailing a bank draft or telephoning to provide the code number for collecting a Western Union transfer).

The second type of transaction cost is the effective exchange rate commission:

$$
\frac{100 * \text { (interbank rate - offered rate) }}{\text { interbank rate }}
$$

which depends on the gap between the offered exchange rate and the interbank rate. The exchange rate commission varies from 2 to 4 per cent for the various New Zealand banks that offer money transfers in Tongan pa'anga. However, for both the international money transfer operators (Western Union and Moneygram) and for a local Tongan operator (Melie mei Langi) the effective exchange rate commission averages almost 10 per cent.

Figure 3 plots the effective transaction costs of remitting (taking into account both fixed charges and the effective exchange rate commission) as a percentage of the amount remitted for a selection of the methods available in the New ZealandTonga remittance corridor. The presence of fixed fees causes the percentage cost to fall as the amount remitted increases, with the greatest percentage costs incurred for remittance amounts under NZ\$200. The exception is Moneygram, where the step function in the fees causes the percentage cost to jump upwards between $N Z \$ 250$ and NZ\$251. It is notable that the survey of Tongan remitters indicated that the median transfer amount in any given transaction was NZ\$ 200 (US\$130), with 10 or more such transactions typically carried out each year. Remitters, therefore, incur greater percentage costs by sending for example, 10 transfers of $N Z \$ 200$ each than they would if they sent a single transfer of NZ\$2,000.

According to figure 3 , it costs between 19 and 31 per cent to send NZ\$ 100 by any method except the recipient using an ATM card to make a withdrawal. The cost to send NZ\$200 is between 15 and 20 per cent, and for $\mathrm{NZ} \$ 300$, it is between 11 and 22 per cent (excluding the ATM card method). Using an ATM card is always the cheapest way to remit money. Melie mei Langi and Western Union are the next cheapest for amounts under the median transfer

4 The other major money transfer operator, Moneygram/Travelex, uses an escalating fee structure, charging more for amounts above NZ\$250, and more again for amounts above NZ\$500. All of the data on these costs were collected in early 2005, when NZ\$100 = US\$ 65 . 
Figure 3. Transaction costs (as percentage of amount remitted) for the New Zealand-Tonga remittance corridor

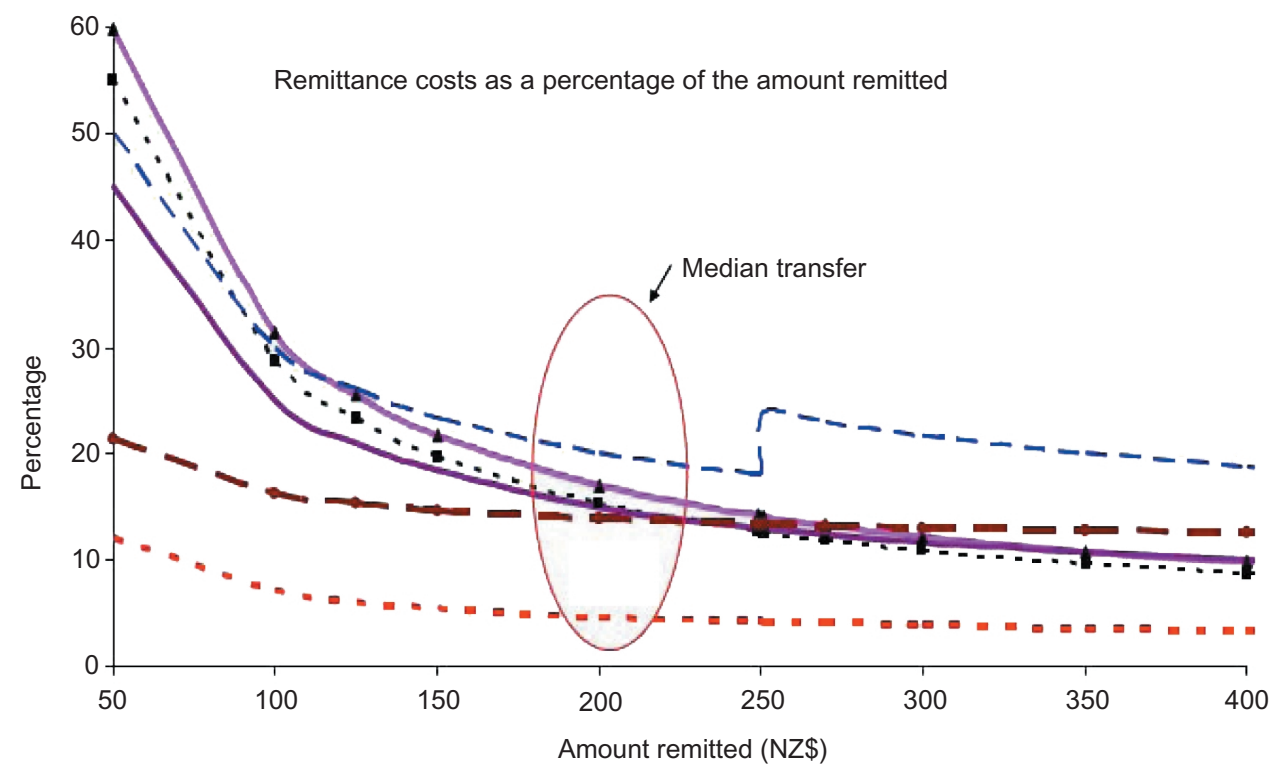

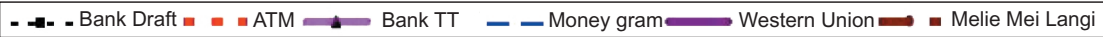

of NZ\$200, after which the bank draft becomes cheaper. Bank drafts and telegraphic transfers are the cheapest, apart from ATMs, for larger amounts.

It is notable that for smaller transfers, the indigenous Tongan company, Melie mei Langi, is more competitive than either the international money transfer operators or the banks (except when using an ATM card). Melie mei Langi is run by a Tongan church but is open to people of any denomination. It charges a fixed fee of NZ\$ 5 for amounts under NZ\$ 1,000 and NZ\$ 10 for higher amounts, and these fees are doubled for transfers to the outer islands of Tonga. Money is transferred in under one hour and can be received at two branches on the main island of Tongatapu and at branches on the outer islands in Vava'u and Ha'apai and on 'Eua. There is one branch in Auckland. The fact that a new entrant without the reputation and financial infrastructure advantages of incumbent banks and money transfer operators can provide a competitive service is suggestive of the presence of some economic rents in the New Zealand-Tonga remittance 
corridor. ${ }^{5}$ Such rents might be competed away, to the benefit of remittance recipients and/or remitters, if additional competitive pressure could be introduced.

Table 1 compares the costs of sending money from New Zealand to Tonga with data from an international comparison of remittance costs undertaken by Orozco (2002). Note that these data are four years old, so competition and technological improvements may have lowered costs further. Despite this caveat, the costs of sending money from New Zealand to Tonga are higher than for all of the country pairs listed, for both banks and money transfer operators. Orozco reports an average cost of 5 per cent for bank-to-bank transfers, and 12 per cent for transfers by money transfer operators, which is almost half the cost of a bank transfer and two thirds the cost of using a money transfer operator to send the same amount from New Zealand to Tonga.

\section{Table 1. Percentage cost of sending US\$ 200 by country}

\begin{tabular}{|lcc|}
\hline \multicolumn{1}{|c}{ Countries of destination and origin } & $\begin{array}{c}\text { Banks } \\
\text { (Percentage) }\end{array}$ & $\begin{array}{c}\text { Money transfer } \\
\text { operators } \\
\text { (Percentage) }\end{array}$ \\
\hline Pakistan (from Saudi Arabia, United States, United Kingdom) & 0.4 & 13.0 \\
Mozambique (from South Africa, United States) & 1.0 &.. \\
Turkey (from Germany, United States) & 3.1 & 9.5 \\
Portugal (from France, United States) & 3.4 & 12.3 \\
India (from Saudi Arabia, United States, United Kingdom) & 6.0 & 13.8 \\
Greece (from Germany, United States) & 6.8 & 9.5 \\
Philippines (from United States) & 8.0 & 10.3 \\
Mexico (from United States) & 8.6 & 10.6 \\
El Salvador (from United States) &.. & 7.2 \\
Dominican Republic (from United States) &.. & 8.5 \\
Tonga (from New Zealand) & $\mathbf{1 2 - 1 3}$ & $\mathbf{1 5 - 2 3}$ \\
\hline
\end{tabular}

Source: Orozco (2002, Tables 7 and 14) and Gibson, McKenzie and Rohorua (2006).

One objection to comparisons such as those in table 1 might be that the volume of remittances being sent to Tonga is lower than that being sent to many of these comparison countries, meaning that differences in scale might explain the higher fees in Tonga. However, two good comparison countries in this respect are Ghana and Mozambique since all three countries received between US\$ 65 million

5 Economic rent is the name given by economists to returns that are higher than those needed to keep resources in their current use, where this higher payment for the resources is typically due to the exploitation of market power. 
and US\$ 70 million in remittances in 2003. ${ }^{6}$ The cost of sending 100 British pounds (approximately US\$ 76) to Ghana is under 5 per cent for seven money operators in the United Kingdom of Great Britain and Northern Ireland, while the cost of a bank transfer from South Africa to Mozambique is only 1 per cent. $^{7}$ Based on these comparisons, it appears that transferring money from New Zealand to Tonga is approximately twice as expensive, on average, as bank transfers to a wide variety of countries from the United States and the United Kingdom, including countries with similar remittance volumes as Tonga.

\section{RELIANCE ON COSTLY METHODS OF REMITTING FROM NEW ZEALAND TO TONGA}

The evidence in section IV suggests that transaction costs are high in the New Zealand-Tonga remittance corridor. However, there is at least one lower-cost alternative, which is for the remittance recipient to have an ATM card linked to a New Zealand bank account set up by the sender. This is a fast and cheap way to send money, with withdrawal fees in the range of NZ\$ 5 to NZ\$ 8 and effective exchange rate commissions that are much lower than those charged by money transfer operators.

Money transfers using ATM cards are also reported by Isern, Deshpande and van Doorn (2005) to be the least expensive of any remittance method in the Latin American market. Moreover, even cheaper methods based on cell phones are becoming available in some remittance markets such as the Philippines. ${ }^{8}$ However, such methods are quite technologically sophisticated compared with the simplicity of setting up a bank account for an immigrant that provides an ATM card for their own use and one for their recipient to use overseas. Hence, the lower transaction costs of cell phone-based methods may not be a good benchmark because they may also entail additional investments (in both hardware and cultural/ technical acceptance) that is not feasible in the Pacific. In contrast, remittances based on ATMs are already known to be feasible in the Pacific, so their transaction

6 The source of this comparison is the World Development Indicators. It is clear from figure 2 that remittance receipts for Tonga have increased sharply since 2003, which would make any scale effect even less likely to account for the higher cost of remitting to Tonga, unless there was a similarly rapid increase in remittances for Ghana and Mozambique.

7 These transaction costs were obtained from <www.sendmoneyhome.org $>$.

8 See Box 6.6 of World Bank (2006), which describes how Filipino immigrants can use a cell phone to deposit money into an "electronic wallet" that can be used by the recipient in the Philippines to either make a withdrawal from an ATM or to pay for a variety of purchases. The transaction cost of this method is about 1 per cent. 
costs provide a feasible benchmark against which the other existing methods can be compared.

Despite their lower cost, ATM cards are an infrequently used method in the New Zealand-Tonga remittance corridor. Instead, a (slight) majority of the Tongan immigrants in the PINZMS sample who had remitted appeared to be using Western Union, which has a transaction cost of 15 per cent for the median transfer of NZ\$200 (see table 2). The other popular choice was Melie mei Langi, which has a similar transaction cost for a transfer of NZ\$200, but is cheaper for small transfers and more costly for larger transfers. But even for Melie mei Langi, whose transaction costs range from 12 to 16 per cent for transfers between NZ\$100 and NZ\$ 500, it is unclear why this channel is preferred over the much cheaper ATM card method.

Table 2. Most frequently used remittance method

\begin{tabular}{|lc|}
\hline \multicolumn{1}{|c|}{ Method } & $\begin{array}{c}\text { Frequency } \\
\text { (Percentage) }\end{array}$ \\
\hline Giving money to someone to take back when traveling & 6.9 \\
Bank transfer through Westpac & 5.6 \\
Bank transfer through other bank & 1.4 \\
Western Union/New Zealand Post Office & 51.4 \\
Travelex & 4.2 \\
Melie mei Langi & 29.2 \\
ATM card or credit card given to recipient & 1.4 \\
\hline
\end{tabular}

Source: Author's calculation from PINZMS data (from $\mathrm{n}=72$ remitters).

While many factors are likely to affect a remitter's choice of method, three are discussed here: knowledge, access and trust. These headings provide a way of examining hypotheses about the continued reliance on high transaction costs methods in the New Zealand-Tonga remittance corridor and more broadly throughout the region.

\section{Lack of knowledge}

In addition to questions about the most frequently used method of remitting, the sample of Tongan immigrants were also asked about methods they had ever used and methods they knew about but had not used. Although a total of 17 methods were covered by the questionnaire, remitters in the PINZMS sample only knew about 3 other methods, on average, besides their most commonly used method. Significantly, only 5.5 per cent of the sample of remitters knew that it 
was possible to use an ATM card linked to a New Zealand bank account to send remittances to Tonga.

The most widely known method was Western Union, with which 97 per cent of the remitters were familiar. The next most widely known methods were Melie mei Langi (known about by 63 per cent) and bank drafts or wire transfers through the major trading banks (ANZ and Westpac), which were known about by 62 per cent. In general, there appears to be limited knowledge of the alternatives to the channels used by the respondents. This lack of knowledge of other remittance methods could account for the continued reliance on high-cost methods, especially given the successful advertising that Western Union undertakes in both Tonga and New Zealand.

\section{Lack of access}

Alternative methods of remitting that have lower transaction costs may not be used if either senders or recipients cannot access them. Lack of access is most likely to affect recipients rather than senders due to the much denser financial infrastructure in New Zealand than in Tonga. In terms of physical access, there are more than 500 New Zealand Post shops in New Zealand where Western Union services can be accessed, a similar number of bank branches and even more ATMs. Moreover, all of the remitters from the sample of Tongan immigrants had bank accounts and 98 per cent of them had ATM cards, so technical access to ATM-based remittance methods is almost universal on the sender side.

However, access for remittance recipients may be more limited and this may be a determining factor in the choice of remittance method. Indeed, Maclellan and Mares (2006) note that an attraction of sending money through Western Union is the ease of access in rural areas and outer islands in the Pacific. A proper understanding of access cannot be obtained without studying the spatial distribution of facilities. Otherwise, a service with many outlets clustered in one location may erroneously seem to be more accessible than one with fewer outlets which are distributed in closer proximity to the population. It is also important to model spatial access using the travel methods that the population relies on rather than assumed methods (such as, as the crow flies straight line distances).

In the light of the above points, the access to ATMs and Western Union outlets was considered for the population on the main island of Tongatapu. The location of each of the eight ATMs (seven of which are located in the capital city of Nuku'alofa) and the five Western Union outlets were geocoded and placed onto a digitized version of the road network to simulate the travel distance that the population would face in reaching their nearest remittance receiving facility. The 
spatial distribution of the population is based on the village-level counts from the Tongan census, which should be an adequate proxy for the distribution of remittance recipients, since 78 per cent of households in Tongatapu received remittances in the most recent survey, (Tonga, 2002) and the PINZMS data reveal no spatial patterns in remittance receipts. The resulting service areas for road travel to the nearest remittance-receiving facility are shown in figure 4 .

Figure 4. Service areas for ATMs and Western Union outlets on Tongatapu, Tonga

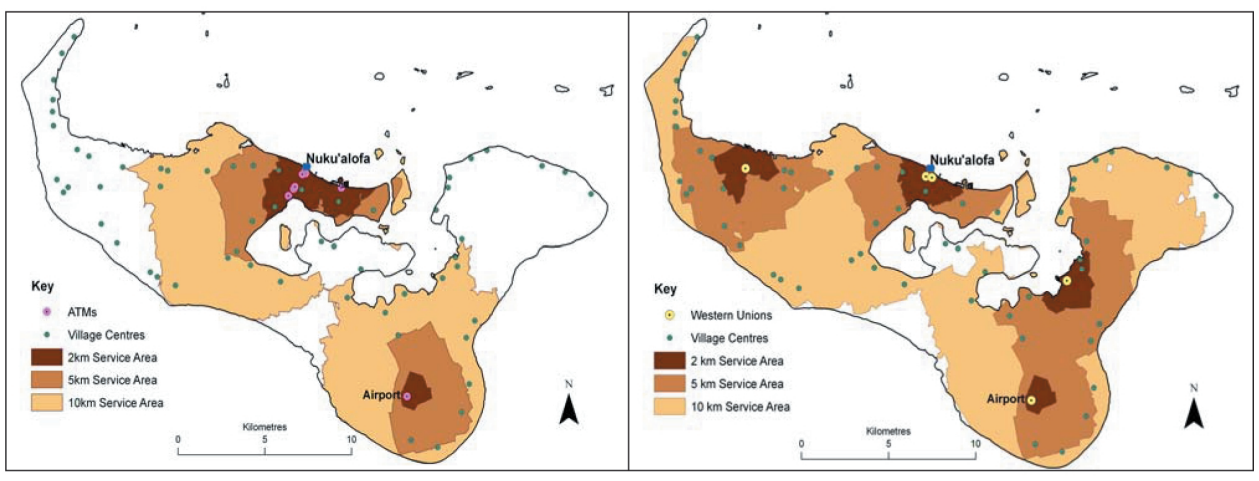

Source: Boe-Gibson (2006).

It is apparent from figure 4 and from table 3 , which provides statistics derived from the maps, that even though there are only five Western Union outlets, their combined service areas for the longest specified travel distance of 10 kilometres covered 97 per cent of the population. In contrast, the corresponding coverage for the eight ATMs is only 77 per cent due to their clustering in Nuku'alofa. The greater population coverage for Western Unions is also apparent within a 5 kilometre service area, where they cover 68 per cent of the population versus 53 per cent for ATMs.

In terms of average travel distance rather than population covered in service areas, the population-weighted mean distance by road from village centres to the closest ATM on Tongatapu is 5.91 kilometres, while the mean distance to the nearest Western Union outlet is 3.97 kilometres (see table 3 ). The median distance is 4.34 kilometres for ATMs and 3.97 kilometres for Western Union outlets. These results suggest that ATMs are about 50 per cent further away than are Western Union outlets for the average person on Tongatapu. 
Table 3. Distance to nearest remittance-receiving facility, Tongatapu

\begin{tabular}{|lcc|}
\hline & ATM & Western Union \\
\hline Mean distance for road travel (kilometres) & 5.91 & 3.97 \\
Median distance for road travel (kilometres) & 4.34 & 2.74 \\
Percentage of population outside 2 kilometres service area & 61 & 68 \\
Percentage of population outside 5 kilometres service area & 47 & 32 \\
Percentage of population outside 10 kilometres service area & 23 & 3 \\
\hline
\end{tabular}

Source: Author's calculations from Boe-Gibson (2006).

The lack of ATMs outside of Nuku'alofa (and the airport) is not due to a lack of potential sites. There are several branches of the Tonga Development Bank and private sector commercial facilities, such as service stations, that have the cash, electricity, security and telecommunications required. Indeed, when the data in figure 4 are used in a simulation analysis to locate two additional ATMs so that they best service the population, while minimizing travel times, the locations chosen are the same as those where Western Union has already located its outlets outside of Nuku'alofa and the airport. In other words, the Western Union outlets appear to be situated in the optimal locations if the aim is to cover the greatest proportion of the population possible with a given number of outlets. Thus, one reason for the continued reliance on costly methods of sending money from New Zealand to Tonga may be that ATMs in Tonga are geographically less accessible for the recipients than Western Union outlets.

\section{Lack of trust}

An even more important reason explaining why high-cost remittance channels like Western Union may be the most popular with remitters is security concerns. Transfers made with Western Union require the remitter to contact the recipient and give them a unique, transaction-specific code in order to obtain the funds from the Western Union outlet. In contrast, the automation provided by ATMs, which gives them a transaction cost advantage, also may cause remitters to feel that they do not have full control of the transactions.

Evidence of these security concerns is found in the responses to questions about the reasons for the choice of remittance method that were asked of a subsample of the Tongan immigrants in New Zealand. ${ }^{9}$ Three quarters of these

9 Specifically, those interviewed after February $2006(n=36)$. These were recent immigrants, mostly arriving in late 2005, and even within their first few months of residence in New Zealand 24 had already sent remittances back to Tonga; it is this group of 24 whose responses are reported here. 
respondents indicated that they would not use ATMs as a method of remitting because they either did not trust the ATM machines in Tonga ${ }^{10}$ or they did not trust their relatives to withdraw only the required amount. This second problem could be easily addressed by having an account dedicated to making transfers which contains only a minimum balance and has no way of accessing the accountholder's other funds in New Zealand. The use of similar accounts in other countries is described by Isern, Deshpande and van Doorn (2005). The security changes made by New Zealand banks after the thefts of ATM details by criminal gangs in early 2006 could also help address the first security concern. However, until those in the remitting community are aware of these ways of guarding the security of their funds, they may be likely to continue using more costly methods of sending money that give them the desired degree of control over the transaction.

\section{DISCUSSION AND CONCLUSIONS}

The results reported here suggest that the average cost of sending money from New Zealand to Tonga is high by international standards, comprising 15-20 per cent of the amount sent for the median remittance transaction of NZ\$200. Lower transaction costs (less than 5 per cent) are available if remittances are made using ATM cards, but this method is very rarely used. Instead, a (slight) majority of remitters use Western Union most frequently, followed by Melie mei Langi, which is a local church-run Tongan company. This cost difference between the most popular and the cheapest remittance methods results in a potential loss of remittance funds actually received in Tonga of an amount equivalent to 4 per cent of GDP.

Three possible reasons for the continued reliance on high transaction cost methods have been discussed: knowledge, access and trust. In terms of knowledge, Tongan immigrants in the PINZMS sample do not appear to be aware of many of the alternatives to their own most frequently used method of sending remittances. In terms of access, ATM machines in Tongatapu are shown to be less geographically accessible than Western Union outlets. Indeed, the Western Union outlets appear to be situated in the optimal locations to reach the greatest portion of the population with a given number of outlets. In terms of trust, remitters appear to have concerns about the security of the ATMs in Tonga and about the security of their money in New Zealand if they provide unrestricted access to their bank account by providing an ATM card to the recipient of the remittances in Tonga.

10 The survey was done at the same time as a large amount of publicity in New Zealand about a criminal gang in Auckland which modified ATMs so that the ATM card details were revealed and then used to make unauthorized withdrawals. This circumstance may have coloured the results. 
Whether these concerns about loss of control over the amount remitted, the security and accessibility of the remittance method and remitters' knowledge of the alternatives can be overcome is a subject for separate research. However, there should be a substantial incentive for innovations along these lines given the very large and potentially avoidable transaction costs that are currently being borne in the New Zealand-Tonga remittance corridor. It should take rather less than 4 per cent of Tongan GDP to inform remitters about alternative methods, to provide additional ATMs and to solve the issues of security and loss of control that will still act as a constraint even if knowledge and access are improved.

Although the empirical results reported in this paper relate only to the New Zealand-Tonga remittance corridor, estimates reported by McKenzie (2007) suggest that transaction costs for remittances from Australia to Fiji, Samoa, Tonga and Vanuatu are at least as high as for those from New Zealand to Tonga. Moreover, transaction costs for sending money from the United States to Tonga are higher than for sending it from New Zealand. ${ }^{11}$ Thus, it is likely that the spread of 10 percentage points between the cheapest and the most widely used remittance methods in the New Zealand-Tonga remittance corridor is similar for other remittance corridors into the Pacific. Consequently, the Pacific as a whole (including the immigrant populations in Australia, New Zealand and the United States) may be losing up to US\$ 40 million per year because remittances (from all sources) are sent through costly rather than cheap channels. This amount might be justified as the price of the services, such as accessibility, familiarity and security, that are provided by the incumbent banks and money transfer operators. However, it can also be viewed as a rent available to be competed away by lower cost operators who introduce more technologically advanced methods into these remittance corridors while still providing sufficient accessibility and security. Finding ways to achieve these more efficient financial services would be a useful activity for the developed countries in the region, which already control many of the banking services and which have all undertaken considerable financial deregulation and sector rationalization in recent years.

A simple but highly effective starting point with benefits for both Pacific island emigrant remitters (who are mainly in New Zealand, Australia and the United States) and for Pacific island economies would be for a non-governmental organization, a Government or a donor agency to maintain a publicly searchable database of the costs and other characteristics of various remittance providers.

11 An exception is an Internet-based money transfer product found at www. Ikobo.com which has lower transaction costs than most methods of sending money from New Zealand, but no members of the PINZMS samples in either New Zealand or Tonga had any knowledge of this method. 
There are at least two examples which could serve as model for such a service. The first is the website www.sendmoneyhome.org, which was created as part of a remittance project of the Department of International Development (DFID) in the United Kingdom. This website has a searchable database that enables would-be remitters to easily compare the services provided by various money transfer operators and banks for transfers from each of 7 immigrant host countries to each of 32 emigrant countries of origin. The fees for both small (£100) and large (£500) transfers are reported along with the net amount that should be received by the recipient and the speed of the transfer. According to DFID (United Kingdom, 2007), the cost of sending money from the United Kingdom to the countries profiled by the www.sendmoneyhome.org website has fallen by 30 per cent, in part due to the greater competition that has resulted from publicizing remittance costs.

The second example is from Profeco, the national consumer protection agency of Mexico, which works with the Mexican consulates in nine United States cities to collect weekly data on the costs of sending money to Mexico. A worksheet is published each week for each city at www.profeco.gob.mx/envio/cuadsacra.asp, showing the cost of sending US\$300, the amount in pesos that would be received, the amount of time needed for delivery and where the money can be picked up in Mexico. This additional information has increased competition in the market for transfers to Mexico, which has been associated with a decrease in costs (Hernández-Coss, 2005). Moreover, Orozco (2002) shows that the cost of sending money to different countries from the United States correlates with the amount of competition in each market.

These examples show the potential benefits to remittance receivingcountries, along with their remittance-sending emigrants, from efforts like these that help to improve the information available to those people involved in remittance transactions. Greater transparency and choice should lead to lower transaction costs, which should help to improve the development impact of remittances in the Pacific. 


\section{REFERENCES}

Adams, R. (2006). "Remittances, poverty and investment in Guatemala", in C. Ozden and M. Schiff, eds., International Migration, Remittances and the Brain Drain (Washington, D.C., World Bank), pp. 53-80.

Asian Development Bank (ADB) (2006). Key Indicators 2006 (Manila).

AusAID (2006). Pacific 2020 Challenges and Opportunities for Growth (Canberra).

Beck, T., A. Demurgic-Kunt and M. Peria (2007). "Reaching out: access to and use of banking services across countries", Journal of Financial Economics, vol. 85, No. 1, July, pp. 234-266.

Benson-Pope, D. and D. Cunliffe (2006). Seasonal work scheme for Pacific workers, (Government of New Zealand), accessed on 29 October 2006 from www.beehive.govt.nz/ ViewDocument.aspx?DocumentID=27496.

Boe-Gibson, G. (2006). "Geographic accessibility of money transfer facilities in Tongatapu", Bachelor of Arts (Hons.) dissertation, University of Canterbury.

Brown, R. (1994). "Migrants' remittances, savings and investment in the South Pacific", International Labour Review, vol. 133, No. 3, pp. 347-366.

Brown, R. and J. Connell (1993). "The global flea market: migration, remittances and the informal economy in Tonga", Development and Change, vol. 24, No. 4, pp. 611-647.

Connell, J. and R. Brown (2005). Remittances in the Pacific: an overview (Manila, Asian Development Bank).

Gibson, J., D. McKenzie and H. Rohorua (2006). "How cost-elastic are remittances? Estimates from Tongan migrants in New Zealand", Pacific Economic Bulletin, vol. 21, No. 1, pp. 112-128.

Helms, B. (2006). Access for All: Building Inclusive Financial Systems, Consultative Group to Assist the Poor (Washington, D.C., World Bank).

Hernández-Coss, R. (2005). The U.S.-Mexico Remittance Corridor: Lessons on Shifting from Informal to Formal Transfer Systems (Washington, D.C., World Bank).

Isern, J., R. Deshpande, and J. van Doorn (2005). "Money transfers: taking advantage of the market opportunity", in Judith Shaw, ed., Remittances, Microfinance and Development: Building the Links, (Brisbane, Foundation for Development Cooperation), pp. 46-51.

Maclellan, N., and P. Mares (2006). Remittances and labour mobility in the Pacific, Working Paper on seasonal work programs in Australia for Pacific Islanders, (Melbourne, Pacific Labour and Australian Horticulture Project, Institute for Social Research, Swinburne University of Technology).

McKenzie, D. (2007). "Remittances in the Pacific", in Susan Pozo, ed., Immigrants and their International Monetary Flows (Kalamazoo, Michigan, W.E. Upjohn Institute for Employment Research), pp. 99-121.

McKenzie, D., J. Gibson and S. Stillman (2007). "Moving to opportunity, leaving behind what? Evaluating the initial effects of a migration policy on incomes and poverty in source areas". New Zealand Economic Papers, vol. 41, No. 2, pp. 197-224.

National Reserve Bank of Tonga (various issues). Quarterly Bulletin (Nuku'alofa). 
Orozco, M. (2002). Worker Remittances: The human face of globalization, Working Paper (Multilateral Investment Fund of the Inter-American Development Bank).

Ratha, D. (2003). "Workers' remittances: An important and stable source of external development finance", Chapter 7 in Global Development Finance 2003 (Washington, D.C., World Bank).

Tonga (2002). Report on the Household Income and Expenditure Survey 2000/01, Statistics Department (Nuku'alofa).

United Kingdom of Great Britain and Northern Ireland (2007). Moving out of Poverty-Making Migration Work Better for Poor People, Department for International Development (DFID) (London).

World Bank (2006). Global Economic Prospects 2006: Economic Implications of Remittances and Migration (Washington, D.C.).

World Bank (2006a). At Home and Away: Expanding Job Opportunities for Pacific Islanders Through Labour Mobility (Washington, D.C.).

World Bank (2007). World Development Indicators (Washington, D.C.). 